\title{
Study on the Allegory Narrative Mode in England, England
}

\author{
Liqin Xie \\ College of Applied Science \\ Jiangxi University of Science and Technology \\ Ganzhou, China
}

\begin{abstract}
Julian Barnes is an important contemporary English writer. In England, England, he continues to try a new writing form of novel. Adopting the non - realistic narrative mode of the allegory narrative, whose style is comic, is Julian Barnes' good exploration to writing techniques. Based on the exploration of the Martha's image and the design of the ambiguous background of time and space, this paper illustrates the allegory narrative mode that Julian Barnes applies in this work.
\end{abstract}

Keywords-Julian Barnes; England; England; the Allegory Narrative

\section{INTRODUCTION}

Julian Barnes is a contemporary English writer. He was born in Leicester, East Midlands, England, on January 19, 1946. His first short story, A Self-Possessed Woman, came out in 1975. His first novel, which was published in 1980, is Metroland, a world-shaking novel about a young man named Christopher Lloyd. This novel was a great success and won the 1981 Somerest Maugham award, which was usually presented to an excellent debut novel. After this novel, Julian Barnes devoted himself to a series of detectives: Duffy (written in 1980), Fiddle City (written in 1981), and Putting the Boot in (written in 1985), Going to the Dogs (written in 1987). Simultaneously, Julian Barnes published many novels such as Before She Met Me in 1982, Flaubert's Parrot in 1984 and Staring at the Sun in 1986. Flaubert's Parrot was the first great success of Julian Barnes, which became the masterpiece of him. This novel won the 1986 Prix Medicis and it was on the shortlist for the Booker Prize. In 1989, he published A History of the World in 101/2 Chapters, which was highly praised by critics. In 1991, Talking It Over was published and won a prize in France. In 1992, The Procupine was published. The collection of his long essays in his own country, Letters from London 1990-1995, was completed when he was a correspondent in London. In 1996, Julian Barnes published his first collection of short stories: Cross Channel. Then in 1998, the novel England, England came out, which was on the shortlist for the Booker Prize. In 2001, he published Love, etc. In 2002, the second collection of essays Something to Declare was published. In 2003, the third collection of essays The Pedant in the Kitchen appeared. In 2004, a mass of short stories The Lemon Table come out. Another voluminous and successful novel is Arthur \& George, which was published in 2005 and was short-listed for the Booker Prize. In 2008, he published Nothing to Be Frightened $O f$, a memoir in multiple thinking, whose theme is family and love. Then, in 2011, his latest work The Sense of Ending appeared. He won the Booker Prize for this latest work, which is declared in December, 2011.

Since starting his career as a novelist in 1980s, Julian Barnes has been known as "the chameleon of British letters". $\mathrm{He}$ is "like the teacher of your dreams: humorous, metaphorical across both popular and unpopular culture, sarcastic". He was regarded as chameleon for his diverse types in writing, for his various themes of his works, for his multifarious experimental writing skills, narrative modes, and perhaps for his different profession he has taken.

This novel is divided into three parts in chronological order. The first part, only covering 23 pages, focuses on Martha Cochrane, a teenager, fond of jigsaws, suspicious of religion and of the validity of memory, suffering the pain of abandonment from father. The second part, with 230 pages, presents a fantasy: media mogul Sir Jack Pitman and his associates (among them there is Martha Cochrane, approaching middle age) turn the Isle of Wright into a gigantic theme park called "England, England", in which one can find replicas of England's best-known historical buildings, sites and figures. The third part, with 25 pages, describes that Martha Cochrane, now an old and wiser woman, has gone back to the former England, a preindustrial era. There are two clues in the novel. The first one is Martha's development and maturity from childhood to teenager to middle age to old age; the second one is Sir Jack Pitman's success in turning the Isle of Wright into a theme park named "England, England". As Vanessa Guignery suggests "this novel plays the satirical public story of Sir Jack Pitman's megalomaniac venture against the private story of Martha's development from teenager to elderly lady". (Guignery 104)

The work England, England appeared in 1998, and at the same year it was at the shortlist for the Booker Prize. After its publication, it is among one of the critical writing about Julian Barnes's works. Vera Nunning deeply analyzes the issue of 'englishness' exemplified in this novel, pointing out that the traditions cannot be repeated. Vanessa Guignery gives a thorough commentary and study of this novel. In his view, this novel is somewhat a common novel; Julian Barnes gives up experiment in narration and techniques but 
choosing the chronological order; gives up attachment to France but focusing on englishness of England; it is a kind of political novel, unique and highly original; Vanessa Guignery points out the themes of England, England: "the elusiveness of truth, the vagaries of love, the construction of history, the relationship between reality and fiction". (Guignery 114)

\section{THE CONNOTATION OF THE AlLEGORY NARRATIVE}

Initially, the allegory is a literary genre. For instance, the famous Aesop's Fables. Afterwards, the allegory develops into a kind of writing symbol, an interpretation way and the subject experience in western in the 20th century and becomes an important concept in cultural criticism in modern society. The modern allegory writing origins from Kafka, whose fable feature of work provides various possibilities for interpretation. The philosopher Walter Benjamin reckons that allegory has a complex and abundant poetic meaning. Therefore, he locates the allegory and regulates the language mode again. He pointed out, "allegory is human's privilege in the era. In a center-dismissed era, after the split of self-awareness, allegory is the only literary form which combines various words. Refusing single-mode has the polyphonic quality. Thus, absorbing the nutrition of allegory is a self-evident thing." (Liu Beicheng, 1998)

Allegory is not only a literary narrative but also a historical narrative. It's an important way of human's creation. It creates the past and the channel of imagination community. People dates back history, which is human's basic pursuit. Because of forgetting, human ensures his childhood with the help of other people's narration. Meanwhile, the nation ensures its own origin and history depending on allegory narrative.

The allegory narrative contributes much to the creation of literature. It helps to tell a good story, it is beneficial to convey the implied theme. Julian Barnes is imaginary and romantic in creating this work England, England. He tells us the history of England in an allegory. And the novel England, England features the allegory narrative, and the allegory narrative is suitable to express the writer's idea in this work. This paper digs into the allegory narrative mode used in this novel from the aspects of the image and the ambiguous background of time and space.

\section{The Allegory FeAture OF IMAGE: MARTHA}

Image is a highly generalization of writer's beautyappreciation, and the allegory narrative text usually presents the split of image and implied meaning, namely the text says A but refers to B. in other words, what is said and what is implied is cracked. Thus, the allegory narrative text not only has a multi-referential function, the image also has some narrative relation beyond the image itself, with the abundant symbolic meaning and profound implied meaning. The heroine in England, England is Martha. From the superficial layer of the story, it seems that this novel can be regarded as a narrative of Martha's journey of exploring real self in her inner heart. The novel describes that little Martha and her father usually play jigsaw games which symbolizes the complete identity of England. It also describes Martha comes to the Isle of Wright in her middle-aged days. She holds the post of adviser in the theme park construction project of "England, England" to look for herself. It also describes Martha comes to Wessex to look for the most original and the most rustic England. So, as the heroine in this work, Martha does what the writer designed. Martha's deeds pushes forward the plot, she is common in plot design, however, from the aspect of theme, Martha is symbolic, she is a vivid form of England, she is a cultural code, she is an undertaker of expressing the connotation of works, and she is an expression of allegory feature. Base on it, the writer adopts the allegory narrative.

\section{AMBIGUITY OF THE BACKGROUND OF TIME AND SPACE}

Ambiguity is a feature of allegory. In this novel, the writer presents three cracked pictures of time and space: the place where Martha lives in her childhood, the Isle of Wright where Martha lives in her middle-aged days, the pastoral countryside where Martha lives in her late years. Those three pictures of time and space are consistent with three parts which form into a narrative respectively. The first part describes Martha's childhood. Because the writer doesn't point out the specific location, the readers can only know that is a certain place where Martha has ever lived. In the second part, the story happens in Martha's middle-aged days. Besides, the readers cannot know the historic time of the story. The Isle of Wright is also imaginary. In the third part, the writer uses Montage technique, focusing on the late years of Martha. The specific time of narrative is still fuzzy. Wessex is also a product of imagination. In a word, in terms of narrative time, the readers only know the corresponding childhood, middle-aged days, late years of Martha. But they don't know the exact historical time of each part. Therefore, the background of time in the story is obscure. In terms of space, the space of the story hasn't been demonstrated vividly. It's a product of writer's imagination. It breaks away from the limit of realistic place and space. Such kind of ambiguity of background of time and space doesn't enable readers to ensure the specific time and the space of the story. It shows the imaginary effect of narrative, which also shows the allegory feature of allegory.

\section{CONCLUSION}

In England, England, Julian Barnes shows a bold innovative spirit, adopting novel allegory narrative, nonrealistic narrative mode, reflecting the englishnesss theme profoundly. To be specific, the writer presents the allegory narrative based on the characterization of Martha and the design of the time and space background. The narrative allegory feature in this work makes readers turn to the reflection and exploration of narrative's implied meaning from reading expectation of a traditional narrative story. This is another good exploration to writing technique used by Julian Barnes.

\section{ACKNOWLEDGMENT}

This is the staged research result supported by Jiangxi Education Department in humanities and social sciences in 
2016 "The Study of Metaphorical Theme in Julian Barnes's Work England, England” (WGW162013)

\section{REFERENCES}

[1] Barnes, Julian. England, England. London: Jonathan Cape, 1998.

[2] Barney, Stephen A. Allegories of History, Allegories of Love. Hamden: Archon, 1979.

[3] Guignery, Vanessa. The Fiction of Julian Julian Barnes. London: Macmillan, 2006.

[4] Yuefen, Fan. Allegory Narrative and Self Writing-On Jamaica Kincaid's the Autobiography of My Mother. [J], Lanzhou Jiaotong University journal, 2015(10).

[5] Beicheng, Liu. The Portrait of Benjamin. [M]. Shanghai: Shanghai Peole's Publishing House, 1998: 79.

[6] Dan, Shen. On Narrative and the Stylistics of Novel. Beijing: Beijing Publishing House, 2004: 143.

[7] Xiayan, Shen. On Allegory Narrative and Nation's Imagination. [J], The Yangtze River Criticism, 2011(2).

[8] Xiaodong, Wu. From Kafka to Kundla. M. Beijing: SDX Joint Publishing Company, 2003:41. 